\title{
Microfinance practice in Batakese traditional wedding party
}

\author{
Niko Saripson P. Simamora ${ }^{1 *}$, Estro Dariatno Sihaloho ${ }^{2}$ \\ ${ }^{1}$ Business Administration, School of Business and Management, Bandung Institute of Technology, Indonesia \\ ${ }^{2}$ Department of Economics, Faculty of Economics and Business, Padjadjaran University, Indonesia \\ *Corresponding author: niko.saripson@sbm-itb.ac.id
}

\begin{abstract}
Indonesia is a multiethnic country. Batak is one of ethnicities in North Sumatera Province. As an ethnicity, Bataks implement the culture as their way of life. Culture came from the ancestors who shaped culture based on their needs at the time. As time goes by and science rapidly develops, culture can be reinterpreted. One example is a way of solving the financing problem with the traditional means.
\end{abstract}

Batakese believe that marriage is one of the most important phases of life. This marriage is often celebrated with the royal wedding party by inviting the family from both sides of bride and bridegroom. The family might come from each of their greatgrandparents. This royal wedding is held with the amount of money, excluding the dowry (sinamot-Batak) which is bride-price that must be paid by bridegroom after negotiating between the families. In general, all of the expenses along the party become the responsibility of bridegroom side.

The burden of the cost that expended by the bridegroom could be balanced from the tumpak, obligatory presents brought by the family of both bride and bridegroom. Tumpak usually consist of money that conforms to the invitee relationship with the bride and bridegroom. The other present, like amount of rice and ulos (traditional woven cloth) could be sold by the family to gain some money. This revenue excludes the presents from the friends, colleague, or others non-family partners.

The Batakese traditional wedding party/ceremony shows a way for microfinance practice to solve the needs of celebrating the wedding party. This paper has objectives to show the local wisdom in financing and the relationship between local practice in microfinance and the institution of microfinance such as cooperative, credit union, and rural banks.
Keywords-Microfinance, Local Wisdom, Cooperative, Credit Union, Rural Bank

\section{INTRODUCTION}

Finance is the science and art of managing money (Gitman \& Zutter, 2015). Microfinance is part of finance that can be defined as finance practice in the microscale of money. The practice of managing money is implemented by individual and group. The term of microfinance more often used as an institution that served the customer with microlending, microcredit, microinsurance, etc. In other words, (Beatriz Armendariz de Aghion, 2005) de Aghion (2005) stated that microfinance emerged as an especially promising way to reduce poverty, fight gender inequality, and strengthen communities.

Microfinance could be understood as a way to solve the financing problem but not limited only as an institution. Most people in the world face financial activities in their daily lives. Everyone has her/his own way to practice those financial activities. In Indonesia, as a multiethnic country, people have their own custom to practice finance and solve money problems. Batak is one of ethnicities in North Sumatera Province, Indonesia. As an ethnicity, people of Batak are implementing their culture as the way of life.

Marriage is one of the important stages of Batakese cultural life. Batakese ethnic group consist of 6 (six) sub-ethnicities: Toba tribes, live around Toba Lake; Mandailing tribes, live around South Tapanuli; Angkola tribes, live around Sipirok and Angkola; Karo tribes, live around Karo highland; Simalungun tribes, stay in Simalungun; Pakpak tribes, live in Dairi or Pakpak land (Bangun, 1982).

Marriage is as important to all six of Batak subethnicities, which is an important role in the Batak socio- 
cultural aspect. Likewise, the Batak Toba, marriage is the first step to be able to participate in the system of Dalihan Na Tolu. Dalihan Na Tolu is a kinship system in the Batak Toba which consists of three elements of the Hula-Hula, Dongan Sabutuha, and Boru (Marbun \& Hutapea, 1987). (Sinaga, 2012) Sinaga (2012) explained that the Hula-hula is greeting the parents and brothers from bride, Dongan Tubu are people who have the same surname with suhut (bridegroom family), and Boru is the husband of the female side of suhut-dongan tubu.

Thus in the Batakese, especially Toba traditional marriage, the wedding ceremony is a bridge which unite Dalihan Na Tolu of bridegroom with Dalihan Na Tolu of the bride (Siahaan, 1982). In addition to comply with requirement of entering Dalihan $\mathrm{Na}$ Tolu, traditional wedding party also becomes an important key to the Batak Toba because through this event the family shall have the right to hold custom events for the child's birth, marriage, death, and other ceremonies. Families who do not hold marriage traditional ceremonies, in Batak Toba language called mangadati, not entitled to give to others and also not entitled accept custom from others (Siregar, 2015).

Traditional Batakese wedding party is costly. It is because the wedding party should invite all the large families of the Dalihan $\mathrm{Na}$ Tolu from bridegroom and bride. For the bridegroom family, in addition to bearing the cost of wedding party, they also must pay a sum of money as a dowry to the woman. At the beginning of marriage, it is commonly defined as the purchase of a bride, in which woman is released from her family after the payment transaction has been agreed in advance. Transactions could be payment with valuables, animals (pigs, buffaloes, cattle) or the amount of money to be given to the woman. The transaction process is called Sinamot (Manik, 2012).

Batakese will find some ways to bear the cost of the traditional wedding party which is not small (Manik, 2012). This is done to implement the customary wedding party because marriage is a very important thing for the Batak Toba. Some efforts that can be done are:

i. Asking for help from family, in the local language called papungu tumpak. Amount of money were collected usually very small. It is not sufficient to cover the cost of the wedding party.

ii. Borrowing to the others or colleagues. To obtain a loan, it would have the requisite for example, a collateral so that not everyone could get it easily.

iii. Selling valuable property which is often done by parents, for example: jewelry, vehicles, land, etc.

Batakese people who uphold the customs could be identified with their strong kinship relations. Batakese society, especially Toba, hold strong familial relationships based on the customs of their ancestors. For the people of Batak Toba, the kinship form emerged based on lineages arising from the pedigree group of clans/surname (Sibeth, 1991). Clan or surname also the one that shows the kinship system of Dalihan Natolu. Tumpak will usually be given by a family who came to the traditional wedding party. Although the amount is small and cannot meet the cost of a wedding party, tumpak is enough to help and show concern of Dalihan Natolu from bridegroom family and Dalihan Natolu from bride family as well.

\section{METHOD}

In this study, all the data used are primary data collected through the interview process of 30 people of the Batak Toba who had been entitled to and can do the custom of Batak Toba. Those Toba people who responded are people who live in urban setting.

The method used in this research is the qualitative method from interview, study of literature, and quantitative method using ordinary least squares process with STATA 12 to get a comprehensive outlook.

Ordinary least-squares (OLS) regression is a generalized linear modeling technique that may be used to model a single response variable which has been recorded on at least an interval scale. The technique may be applied to single or multiple explanatory variables and also categorical explanatory variables that have been appropriately coded (Hutcheson, 2011).

\section{RESULTS}

Below is the result of our interview with 30 respondents. These data illustrate the custom of Batakese people, especially Toba tribes, in attending traditional wedding parties/ceremonies.

Table 1. Number of Attending Batakese Traditional Wedding Party/Ceremony (in the latest month) 
Table 1 shows people of Toba attend traditional wedding party at least once in a month. In the other hand, there also some people who attend the traditional wedding ceremonies more than four times in a month. It can be said that, they might attend a traditional wedding party more than once in a week. It is quite surprising since most of the Batakese arrange their ceremony on Saturday, then some people also attend the party on Friday.

In order to attend the traditional Batakese wedding party, people of Batak have to bring an obligatory gift such as: tumpak consist of money, ulos (traditional woven cloth), or amount of rice. Below is the table that shows the type of traditional gift given by the respondents when attending the traditional wedding party/ceremony (Table 2).

\section{Table 2. Type of Gift Given in Batakese Traditional Wedding Party/Ceremony}

Table 3 shows the amount of rice given to the party, usually brought in a tandok (a traditional webbed pandanus bag). Tandok would be brought by women on their heads when entering the party. A half of respondents bring $5 \mathrm{~kg}$ of rice to the wedding party. It is equal to IDR 50,000 if the price of one kilogram rice is IDR 10,000 (Oct. 2016). That rice can be sold after the wedding ceremony.

\section{Table 3. Amount of Rice Given in Batakese Traditional Wedding Party/Ceremony}

The following table (Table 4) shows the price of ulos brought by the respondent to the traditional wedding party. These ulos can be sold after the wedding party. Some people collect the ulos and use it as their tumpak to future wedding parties/ceremonies of their relatives.

\section{Table 4. Price of Ulos}

Money as a tumpak is a compulsory thing. As an entrant to a Batakese traditional wedding party/ceremony, people at least bring an envelope containing money. The host party can use this amount money to cover the cost of their ceremony. Table 5 below shows the amount of money given to the wedding party.

\section{Table 5. Amount of Money Given in Bataknese Traditional Wedding Ceremony}

Besides data about tumpak, the respondents also asked about whether they ever hosted a traditional wedding party. The total cost that they spend varies, in average about IDR 162 millions. As this traditional wedding ceremony is a custom of the Batakese, they are very happy to organize it. Most of them are satisfied with total earning that come from collected tumpak. If it is in deficit, they usually borrow from their close relatives or colleagues. But if it is a surplus, the host party will be happier.

From our data we get the interval of total marriage cost from bridegroom side from IDR 50 million to IDR 500 million including dowry/sinamot. While if it is excluding dowry the cost is from IDR 30 million to IDR 150 milllion. The bride side also spends a total marriage cost from IDR 50 million to IDR 250 million. This indicates that the bridgegroom most likely spends bigger than the bride.

We calculate the dowry (sinamot) in relation with the marriage cost using ordinary least-squares method in STATA 12. The result is shown in Table 6 below.

\section{Table 6. Relation Between Dowry/Sinamot and Total Marriage Cost in Batak Toba}

The data above shows the relationship between the number of total marriage costs to be incurred by the bridegroom against the number of sinamot given to the bride. The value of sinamot positively affect the value of marriage costs which means that the total cost of the marriage party will be increased if the amount of sinamot increased. The marriage cost will be increased by IDR 1 when sinamot is increased by IDR 2.7 .

The regression results above also show that calculated $t$ is at 5.01 larger than the t-table of 2.8 with a significance level of $99 \%$. The t-test showed that value of sinamot significantly affect the total cost of the wedding ceremony. Interview data indicate that the lowest sinamot is IDR 20 million with the total cost of the wedding IDR 100 million and the highest sinamot is IDR 100 million with the total wedding cost IDR 500 million.

\section{Table 7. The Relation Between Tumpak and Ulos Price in Batak Toba Marriage}


Each person or family that attend the wedding party is likely to bring tumpak (money) and ulos (traditional woven cloth) at the same time. The Table 6 above is a regression that shows relationship between price of ulos given with the value of tumpak given simultaneously at a wedding ceremony of Batak Toba. Calculated $t$ is -0.69 on the regression results above show that the effect of the price of ulos on tumpak value is insignificant or the two are unrelated. This is relevant with the interview results, where respondents indicate that in the Batak Toba customs, the value of tumpak does not influence the ulos price given. It is influenced by the individual/family/clan position in Dalihan $\mathrm{Na}$ Tolu (kinship).

\section{DISCUSSION}

This research is about the marriage of men and women in general of Batak Toba custom. For further research, it is necessary to distinguish how much wedding expenses are borne by the men and the women. It also needs data on the value of tumpak, rice, ulos in rupiah so that we can calculate the number of those invited necessary to cover the cost of a wedding party in Batak Toba.

In a subsequent study it will require a larger number of respondents to show stronger interpretation. In the future, it is also necessary to examine the other Batak tribes.

\section{CONCLUDING REMARKS}

From the data above, we can conclude the following: 1. People of Batak, especially Toba tribe attend a minimum one traditional wedding party in a month and they have to bring traditional gift like tumpak, rice and/or ulos to that wedding party.

2. The total cost of hosting a Batakese traditional wedding party varies. It is related to the sinamot given to the bride. The ceremony may incur a deficit or it can earn a surplus related to earning from tumpak. Since this is an obligatory ceremony for Batak people, they have to arrange the traditional wedding party regardless whether it is deficit or surplus.

3. We may say that the Batakese traditional wedding party is a custom-based practice of microfinance. Batak people's lives are dominated by a strong kin relationship (Dalihan Natolu), so they first ask help to the family and they tend to avoid borrowing money from commercial microfinance institution like cooperatives, credit unions, or rural banks.

Conflict of interest: the data used in this research came from the upper middle class of Batak people who live in urban areas. The result might have been different if the data are obtained from the middle to the bottom of the income classes or who live in rural areas.

\section{ACKNOWLEDGEMENT}

We would like to thank the members of Perkumpulan Gaja Toba Semesta (PGTS) who actively contributed as respondents in this research.

\section{REFERENCE}

Bangun, P. (1982). Kebudayaan Batak . Jakarta:

Koentjaraningrat-Manusia dan Kebudayaan di Indonesia.

Beatriz Armendariz de Aghion, J. M. (2005). The

Economics of Microfinance. Cambridge: The MIT Press.

Gitman, L. J., \& Zutter, C. J. (2015). Principle of Managerial Finance. Edinburgh: Pearson Education.

Hutcheson, G. D. (2011). Ordinary Least-Squares Regression. Dalam G. D. Hutcheson, \& L. Moutinho, The SAGE Dictionary of Quantitative Management Research (hal. 224-228). Manchester: Sage Publications.

Manik, H. S. (2012). Makna dan Fungsi Tradisi Sinamot dalam Adat Perkawinan Sukubangsa Batak Toba di Perantauan Surabaya. BioKultur.

Marbun, M., \& Hutapea, I. (1987). Kamus Budaya Batak Toba. Jakarta: Balai Pustaka.

Siahaan, N. (1982). Adat Dalihan Na Tolu Prinsip dan Pelaksanaannya. Jakarta: Grafina.

Sinaga, Y. V. (2012). Ruang dan Ritual Adat

Pernikahan Suku Batak Toba. Depok: Universitas Indonesia.

Siregar, M. (2015). Konsumerisme dalam Upacara Perkawinan Batak Toba di Kota Denpasar. Denpasar: Universitas Udayana. 
Table 1. Number of Attending Batakese Traditional Wedding Party/Ceremony (in the latest month)

\begin{tabular}{|c|c|c|}
\hline $\begin{array}{c}\text { Number } \\
\text { of visit }\end{array}$ & $\begin{array}{c}\text { Number of } \\
\text { Respondent }\end{array}$ & $\%$ \\
\hline 1 & 12 & $40 \%$ \\
\hline 2 & 5 & $17 \%$ \\
\hline 3 & 5 & $17 \%$ \\
\hline 4 & 3 & $10 \%$ \\
\hline 5 & 0 & $0 \%$ \\
\hline 6 & 3 & $10 \%$ \\
\hline 7 & 0 & $0 \%$ \\
\hline$>8$ & 2 & $7 \%$ \\
\hline
\end{tabular}

Table 2. Type of Gift Given in Batakese Traditional Wedding Party/Ceremony

\begin{tabular}{|l|l|l|}
\hline Type of Gift & $\begin{array}{l}\text { Number of } \\
\text { Respondent }\end{array}$ & $\%$ \\
\hline $\begin{array}{l}\text { Rice, Ulos, } \\
\text { Money }\end{array}$ & 12 & $40 \%$ \\
\hline Ulos, Money & 9 & $30 \%$ \\
\hline Money & 9 & $30 \%$ \\
\hline
\end{tabular}

Table 3. Amount of Rice Given in Batakese Traditional Wedding Party/Ceremony

\begin{tabular}{|c|c|c|}
\hline $\begin{array}{c}\text { Amount of } \\
\text { Rice }(\mathrm{kg})\end{array}$ & $\begin{array}{c}\text { Number of } \\
\text { Respondent }\end{array}$ & $\%$ \\
\hline 5 & 6 & $50 \%$ \\
\hline 4.5 & 1 & $8 \%$ \\
\hline 3 & 1 & $8 \%$ \\
\hline 2 & 1 & $8 \%$ \\
\hline 1.5 & 1 & $8 \%$ \\
\hline 1 & 1 & $8 \%$ \\
\hline
\end{tabular}

Table 4. Price of Ulos

\begin{tabular}{|c|c|c|}
\hline $\begin{array}{c}\text { Price of Ulos } \\
\text { (Rp) }\end{array}$ & $\begin{array}{c}\text { Number of } \\
\text { Respondent }\end{array}$ & $\%$ \\
\hline 50.000 & 3 & $14 \%$ \\
\hline 100.000 & 6 & $29 \%$ \\
\hline 150.000 & 7 & $33 \%$ \\
\hline 200.000 & 3 & $14 \%$ \\
\hline 300.000 & 2 & $10 \%$ \\
\hline
\end{tabular}


Table 5. Amount of Money Given in Bataknese Traditional Wedding Ceremony

\begin{tabular}{|c|c|c|}
\hline $\begin{array}{c}\text { Amount of } \\
\text { Money (Rp) }\end{array}$ & $\begin{array}{c}\text { Number of } \\
\text { Respondent }\end{array}$ & $\%$ \\
\hline 50.000 & 5 & $17 \%$ \\
\hline 100.000 & 11 & $37 \%$ \\
\hline 150.000 & 5 & $17 \%$ \\
\hline 200.000 & 5 & $17 \%$ \\
\hline 250.000 & 2 & $7 \%$ \\
\hline 300.000 & 2 & $7 \%$ \\
\hline
\end{tabular}

Table 6. Relation Between Dowry/Sinamot and Total Marriage Cost in Batak Toba

\begin{tabular}{|c|c|c|c|c|c|c|}
\hline Source & SS & df & MS & & \multirow{2}{*}{$\begin{array}{l}\text { Number of obs }= \\
\text { F }(1, \quad 28)= \\
\text { Prob }>\text { F }\end{array}$} & 30 \\
\hline Model & $2.1934 \mathrm{e}+17$ & $1 \quad 2.19$ & $e+17$ & & & $=0.0000$ \\
\hline Residual & $2.4435 \mathrm{e}+17$ & $\begin{array}{ll}28 & 8.72\end{array}$ & $e+15$ & & R-squared & $=0.4730$ \\
\hline Total & $4.6368 \mathrm{e}+17$ & $29 \quad 1.59$ & $e+16$ & & Root MSE & $=9.3 e+07$ \\
\hline narried_cost & Coef. & Std. Brr. & $\mathrm{t}$ & $P>|t|$ & [958 Conf. & Interval] \\
\hline sinamot & 2.770893 & .5526988 & 5.01 & 0.000 & 1.638741 & 3.903046 \\
\hline _cons & $8.29 \mathrm{e}+07$ & $3.27 e+07$ & 2.53 & 0.017 & $1.59 \mathrm{e}+07$ & $1.50 \mathrm{e}+08$ \\
\hline
\end{tabular}

Table 7. The Relation Between Tumpak and Ulos Price in Batak Toba Marriage

\begin{tabular}{|c|c|c|c|c|c|c|}
\hline Source & sS & $d f$ & MS & & \multirow{2}{*}{$\begin{array}{l}\text { Number of obs }= \\
\text { F( 1, 28) } \\
\text { Prob > F }\end{array}$} & \multirow{2}{*}{$\begin{array}{l}=30 \\
=\quad 0.47 \\
=0.4970\end{array}$} \\
\hline Model & $2.5283 e+09$ & \multicolumn{2}{|c|}{$2.5283 e+09$} & & & \\
\hline Regidual & $1.4947 \mathrm{e}+11$ & $28 \quad 5.33$ & $5.3383 e+09$ & & $\begin{array}{l}\text { R-squared } \\
\text { Adj R-squared }\end{array}$ & $=0.0166$ \\
\hline Total & $1.5200 \mathrm{e}+11$ & $29 \quad 5.24$ & $4 \mathrm{e}+09$ & & Root MSE & $=73064$ \\
\hline tuppak & Coef. & Std. Err. & $\mathrm{t}$ & $p>|t|$ & [958 Conf. & Interval] \\
\hline ulos_price & -.1031941 & .1499495 & -0.69 & 0.497 & -.4103517 & .2039635 \\
\hline _cong & 150491.4 & 20257.06 & 7.43 & 0.000 & 108996.7 & 191986.1 \\
\hline
\end{tabular}

